\title{
Evaluating The Impact of Strigolactone GR24 On Capparis Spinosa L. Callus Production And Phenolic Compound Content
}

Hafsatu Issah

Suleyman Demirel University: Suleyman Demirel Universitesi

Ragbet Ezgi Duran ( $\square$ ezgiduran@sdu.edu.tr)

Suleyman Demirel Universitesi https://orcid.org/0000-0003-0853-3680

\section{Research Article}

Keywords: Capparis spinosa L., callus, strigolactone, GR24, secondary metabolites

Posted Date: July 6th, 2021

DOl: https://doi.org/10.21203/rs.3.rs-484762/v1

License: (c) (1) This work is licensed under a Creative Commons Attribution 4.0 International License.

Read Full License 


\section{Abstract}

The effect of strigolactones on plants, which has been recently described as a new group of plant hormones, has not been fully characterized. Capparis spinosa L. callus formation using synthetic strigolactone GR24 (0.1 and $0.2 \mu \mathrm{M})$ alone or in combination with 1-naphthalene acetic acid (NAA) (2 mg $/ \mathrm{L}$ ) and 6-benzylaminopurine (BAP) (1 mg / L) and its effect on phenolic substance production were evaluated. $2 \mathrm{mg} / \mathrm{L} \mathrm{NAA}+1 \mathrm{mg} / \mathrm{L}$ BAP+0.1 $\mu \mathrm{M}$ GR24 was the medium with the highest callus formation $(60.3 \%)$ and callus fresh weight $(120.8 \mathrm{mg})$. In the phytochemical analysis, the highest total flavonoid and phenolic substance and the highest rutin, quercetin, chlorogenic acid content were found in this application and their amounts increased at various rates compared to the control. Aromatic substances in caper calluses were grouped as sulfur compounds (66.97\% -87.53\%), aldehydes (4.88\% -7.90\%), ketones ( $0.34 \%-19.3 \%)$, hydrocarbons and derivatives (0.56\%-5.8\%), alcohols (\% 1.62-6.08\%), others $(0.61 \%-2.37 \%)$ and their amounts varied at various hormone applications. When $0.1 \mu \mathrm{M}$ GR24 was applied alone, the total sulfur compound in callus samples was $87.53 \%$ and the dominant substance was found to be methyl isothiocyanate.

\section{Introduction}

Capers are plants from the Capparaceae family, tropical/subtropical, states with more than 350 varieties and can grow naturally in all continents, including Mediterranean countries. Capers as perinnniels and shrubs have 250 species in the world (Musallam et al. 2012), while in Turkey's flora there are two species (Capparis spinosa L. and Capparis ovata Desf.) and a total of six different varieties $C$. spinosa var. spinosa, C. spinosa var. inermis Turra., C. spinosa var. aegyptia (Lam) Boiss, C. ovata var. palaestina Zoh., C ovata var. herbacea (wild) Zoh., and C. ovata var. canescens (Coss.) Heywood has been detected (Davis 1982).

Numerous chemical compounds such as alkaloids (Capparispine), flavonoider, lipids, polyphenols, terpenes, indoles, and aliphatic glucosinolates are found in various parts of $C$. spinosa (Arena et al. 2008; Rajesh et al. 2009; Wang et al. 2009), in many studies various parts of caper are used in the treatment of different diseases such as rheumatism, hypertension and diabetes. Sher and Alyemeni (2010) reported that $C$. spinosa is a safe plant and there are no studies in the scientific literature showing its toxic effect.

It is difficult to produce $C$. spinosa by common propagation methods. For example, seed propagation of capers is not preferred due to seed dormancy and high heterozygosity. However, vegetative cutting of caper production is less successful due to rooting problem (Musallam et al. 2011). Many studies have been conducted on the seed dormancy caused by the negative ecological conditions during the germination phase and the negativities arising from the structure of the seed and the ways to eliminate it (Sozzi and Chiesa 1995; Bahrani et al. 2008; Germanà and Chiancone 2009).

Nonetheless, the use of in vitro culture techniques is seen as a very good option to overcome the propagation problems of capers and also for mass production without threatening natural resources. 
There have been many studies showing the effect of these growth regulators BAP, 2,4-D and NAA on callus formation (Tyagi et al. 2010; Kumari et al. 2015). Although it is known that strigolactones regulate plant growth and development especially with other plant hormones such as auxin and cytokinin (Wang et al. 2007; Koltai 2015) there are very few studies evaluating the effect of this hormone concerning in vitro success (Wu et al. 2017).

Our study is the first protocol to evaluate the effect of various strigolactone concentrations on callus formation and phenolic content in caper plant. In the context of this study, it was aimed to evaluate the effect of synthetic strigolactone GR24, which will be used in various concentrations with BAP and NAA, on callus formation and fresh weight. It is also aimed to investigate the amount of phenolic and aromatic substances such as rutin and quercetin in the calli formed.

\section{Materials And Methods}

Plant material and establishment of callus culture

Caper seedlings (Capparis spinosa L.) were used as material in thıs study which was conducted in Süleyman Demirel University Biology Department Plant Biotechnology Laboratory between 2020-2021. The seedlings were planted at a depth of approximately $10 \mathrm{~cm}, 2$ in each pot containing $1 / 3$ sand-peat mixture. From the planting of the seedlings, the plants were under 16 hours / day 8 hours night photoperiod, $135 \mu \mathrm{mol} \mathrm{m} \mathrm{m}^{-2} \mathrm{~s}^{-1}$ PAR light intensity, $23-25^{\circ} \mathrm{C}$ temperature and $51-54 \%$ humidity (measured with Peak Tech 3695) conditions and were grown in the plant growth cabinet for an average of 3 months.

Young leaves between 1.5 and $2.5 \mathrm{~cm}$, taken from caper seedlings were used as explants. These were cut from the stem and washed with tap water until they were cleared of the soil, then rinsed in $70 \%$ ethanol for 10 minutes. Afterwards, they were rinsed 3-4 times with sterile distilled water, $1 \%$ sodium hypochlorite ( $\mathrm{NaOCl}$ ) containing 1-2 drops of Tween-20 for 10 minutes, and surface sterilization was completed by rinsing 3-4 times with sterile distilled water.

With a sterile scalpel, explants pieces of the size $0.5-1 \mathrm{~cm}$ were inoculated onto the culture medium with pinset. 3\% (w/v) sucrose, $0.7 \%(\mathrm{w} / \mathrm{v})$ agar and MS (Murasige and Skoog 1962) medium (Sigma-M9274) containing NAA, BAP and various concentrations of GR24 were used as the culture medium. Previous studies on capers stated that the NAA and BAP ratio has significant effects on callus formation (Kumari et al. 2015). For this reason, $2 \mathrm{mg} / \mathrm{L}$ NAA and $1 \mathrm{mg} / \mathrm{L}$ BAP were accepted as the control group and 4 separate combination groups were established as indicated below.

1. NAA (2 mg/L) + BAP (1 mg/L) (Control)

2. NAA $(2 \mathrm{mg} / \mathrm{L})+\mathrm{BAP}(1 \mathrm{mg} / \mathrm{L})+\mathrm{GR} 24(0.1 \mu \mathrm{M})$

3. NAA $(2 \mathrm{mg} / \mathrm{L})+\mathrm{BAP}(1 \mathrm{mg} / \mathrm{L})+\mathrm{GR} 24(0.2 \mu \mathrm{M})$

4. GR24 $(0.2 \mu \mathrm{M})$ 
The $\mathrm{pH}$ of the culture medium was adjusted to 5.8 using $1 \mathrm{M} \mathrm{NaOH}$ and $1 \mathrm{M} \mathrm{HCl}$, and then autoclaved at $103 \mathrm{kPa}$ pressure $121^{\circ} \mathrm{C}$ for 20 minutes. The media were transfered into sterile petri dishes of $9 \mathrm{~cm}$ diameter with an average of $20 \mathrm{ml}$ each. An average of 10-15 explants were planted in a petri dish, covered tightly with parafilm tape to prevent contamination and incubated for $4-5$ weeks at $22^{\circ} \mathrm{C} \pm 1$ temperature under dark conditions. The explants were then subcultured for 10 days in $2 \mathrm{mg} /$ I NAA, $1 \mathrm{mg}$ / I BAP and $30 \mathrm{~g} 99 \%$ L-rhamnose medium.

For each hormone combination, the number of explants placed in the culture medium and the number of callus formed were recorded. The percentage value was found with the ratio of the number of callus obtained to the number of explants as shown in the formula below.

Callus induction frequency $(\%)=[($ Number of callus $) \div($ Total number of explants $)] \times 100$

The fresh weight of each callus was recorded and taken into eppendorf tubes then stored at $-18^{\circ} \mathrm{C}$ until the examination of the chemical accumulation of the phenolic compounds.

Determination of phenolics and aromatics

Sample analysis were performed at the Innovative Technologies Application and Research Center in Suleyman Demirel University. Callus samples $(1000 \mathrm{mg})$ were weighed and homogenized with $10 \mathrm{~mL}$ of methanol in a homogenizer (IKA T 25 Ultra-Turrax®, Staufen, Germany). The mixture obtained was filtered with a $0.45-\mu \mathrm{m}$ filter (Minisart ${ }^{\circledR}$, Sartorius Stedim Biotech, France) and then evaporated to dryness in an evaporator (Heidolph Hei-VAP G1, Schwabach, Germany) at $40^{\circ} \mathrm{C}$. The dry extract was then dissolved in $1 \mathrm{~mL}$ of methanol and $20 \mu \mathrm{L}$ was transfered into the HPLC apparatus. The HPLC system was equipped with a LC-10ADvp pump, SIL-10AD vp auto-sampler and CTO-10Avp column oven (Shimadzu, Kyoto, Japan). Agilent eclipse XDB-C18 $(250 \times 4.60 \mathrm{~mm}, 5 \mu \mathrm{m})$ column and a mobile phase consisting of methanol and acetic acid ( $3 \% \mathrm{v} / \mathrm{v})$ in water. The flow rate was $0.8 \mathrm{~mL} \mathrm{~min}^{-1}$ and the injection volume was $20 \mu \mathrm{L}$. Column temperature was set to $30^{\circ} \mathrm{C}$. Diode array detector (DAD) worked at $\lambda \max =278 \mathrm{~nm}$, and chromatograms were obtained at various wavelengths according to absorption maxima of the analyzed compounds.

For aromatics, the system was known as fused silica SPME fiber assembly Carboxen/Polydimethylsiloxane (CAR/PDMS) (Sigma-Aldrich ${ }^{\circledR}$ ) with a column of Restek Rx-5Sil MS (30 $\mathrm{m} \times 0.25 \mathrm{~mm}$ i.d., $0.25-\mu \mathrm{m}$ film thickness) (Restek Corporation, Bellefonte, PA). The flow rate of helium as a carrier gas was $1.61 \mathrm{~mL} \mathrm{~min}-1$. The injector temperature was set to $250^{\circ} \mathrm{C}$ for splitless injection. After $2 \mathrm{~min}$ at $40^{\circ} \mathrm{C}$, the system reached $250^{\circ} \mathrm{C}$ with $4^{\circ} \mathrm{C}$ increments per minute and waited for $5 \mathrm{~min}$ at $250^{\circ} \mathrm{C}$. Mass spectra were taken at $70 \mathrm{eV}$. The sample stood for $30 \mathrm{~min}$ with fiber, for $15 \mathrm{~min}$ without fiber at $60^{\circ} \mathrm{C}$, and desorbed at $250^{\circ} \mathrm{C}$. Relative percentage amounts of the separated aromatic compounds were calculated from the total ion chromatograms displayed by the computerized integrator (Shimadzu, Kyoto, Japan).

\section{Statistical analysis}


Pattern of Randomized block design was used for the trials and were conducted at least 3 times. The Oneway-ANOVA of the SPSS 23.0 package program was used for the variance analysis of the data, and the Duncan Multiple Comparison Test was used for the comparison of the means. Graphs for all experimental data were constructed to determine whether the mean values between the different treatment concentrations held a significant difference.

\section{Results And Discussion}

\section{Callus induction and fresh weight}

The effects of strigolactones on plants are not yet fully defined and it is unknown whether the observed effects are universal across plant species. 0.2 $\mathrm{MM}$ GR24 used alone in this study significantly reduced both callus formation and fresh weight $(P<0.05)$. While $0.2 \mu \mathrm{M}$ GR24 used with NAA + BAP significantly reduced the incidence of callus formation, but had no significant effect on fresh weight. Fresh weight measurements showed similar trends in the control group and GR24 combined with NAA + BAP (Fig. 1). Mdodana (2012) found that strigolactone-deficient and insensitive mutants of wild-type $A$. thaliana Col-O were widely used in callus culture, also the media containing various amounts of 2,4-D and kinetin (2: 2 $\mathrm{mg} / \mathrm{L}$ or $0.5: 0.05 \mathrm{mg} / \mathrm{L}$ ) were successful and when these calluses were transferred onto media containing $0.1 \mu \mathrm{M}$ GR24 and auxin or cytokinin, the amount of callus biomass increased in some of the mutants. Grobbelaar et al. (2014) demonstrated that strigolactones (GR24 and Nijmegen-1 $(0.1 \mu \mathrm{M})$ generally had a minimal effect on the growth of Salvia frutescens nodal explants. However, when combined with $1 \mathrm{mg} / \mathrm{L}$ NAA, these hormones promoted biomass production. Similar results were also shown by Zulfiqar et al. (2020) in which $0.01 \mathrm{mg} / \mathrm{L}$ GR24 was the optimum amount for the callus growth of Helianthus annuus $\mathrm{L}$. In this study, the frequency of in vitro callus formation and fresh weight were similar in amount to the control group but the highest was found in the 2NAA + 1BAP + $0.1 \mu \mathrm{M}$ GR24 medium, indicating the synergistic relationship between auxins and strigolactones (Brewer et al. 2009; Hayward et al. 2009; Agusti et al. 2011).

Production of phenolic and aromatic compounds

As the main active compound, flavonoids play a notable role in a variety of pharmacological activities, including antiallergic, anti-inflammatory and antioxidant effects (Trombetta et al. 2005, Panico et al. 2005). Germano et al. (2002), Matthaus and Özcan (2005), Tlili et al. (2009) reported that the caper plant is a rich plant source of flavonoid compounds rutin (rutocide) and quercetin, also different parts of the plants contained phytosterols, tocopherols, carotenoids and glucosinolates. In literature reviews, no study has been found concerning the effect of GR24 on the amount of phenolic compounds in $C$. spinosa callus. In this study, the total flavonoid in the $2 \mathrm{mg} L \mathrm{NAA}+1 \mathrm{mg} / \mathrm{L} B A P+0.1 \mu \mathrm{M}(\mathrm{P}<0.05)$ treatment increased by $19 \%$ when compared to the control. Goda et al. (2017) found that the total flavonoid content in $C$. spinosa callus from the 2,4-D medium was $0.85 \mathrm{mg} / 100 \mathrm{mg}$. It has also been stated in many studies that the rutin contained in the aerial parts were dominant flavonoid (Zhou et al. 2011; Argentieri et al. 2012). In our study except $0.2 \mu$ M GR24, rutin was the dominant flavonoid in leaf calluses obtained from 
all applications, and its content in $2 \mathrm{mg} / \mathrm{L} \mathrm{NAA}+1 \mathrm{mg} / \mathrm{L} \mathrm{BAP}+0.1 \mu \mathrm{M}$ GR24 application increased approximately by 1.5 times when compared to the control group and the amount found was $16.9 \mu \mathrm{g} / \mathrm{g}$ DW $(P<0.05)$. While the GR24 applied alone significantly reduced the rutin content, the low concentration of GR24 used with NAA and BAP positively affected the amount of rutin (Fig. 2).. Tlili et al. (2010) found the rutin content of caper plant leaves collected from Tunisia flora as $13.52 \mathrm{mg} / 100 \mathrm{~g}$, Behnaz et al. (2013) aslo examined the amount of rutin and quercetin in various parts of the capers and reported that the highest was found in the leaves at 25.2 and $10.4 \mathrm{mg} / \mathrm{g}$ respectively.

Palacio et al. (2012) found the amount of quercetin from the callus of Larrea divaricata leaves treated with $2 \mathrm{mg} / \mathrm{L} 2.4 \mathrm{D}$ and $1 \mathrm{mg} / \mathrm{L}$ BAP to to be approximately $6 \mu \mathrm{g} / \mathrm{g}$. In our study, quercetin was almost the same amount in all other applications (5.1-5.4 $\mu \mathrm{g} / \mathrm{g} \mathrm{DW}$ ) except for the $0.2 \mu \mathrm{M}$ GR24 application (quercetin was zero) (Fig. 2). This suggests that NAA and BAP are effective hormones in the accumulation of quercetin. According to many in vitro studies it is recommended to add BAP to the culture medium to increase the production of various secondary metabolites in plants. For example, AlAshoush (2017) and Udomsuk et al. (2009) reported that BAP had a positive effect on the amounts of some secondary metabolites in addition to the total isoflavonoids extracted. In addition, it has been documented that kinetin affects polyphenol groups such as quercetin and isomer by interfering with the synthesis of nucleic acids that can affect polyphenol production (Shah et al. 1976).

Kaempferol amount varied between 4.8 and $3.3 \mu \mathrm{g} / \mathrm{g}$ DW in applications (Fig. 2). Tlili et al. (2017) determined the amount of kaempferol in caper leaf extracts as 3.63\%. Haifa et al. (2016) could not detect kaempferol in C.spinosa leaves in the Tunisian flora.

The total amount of phenolic substance increased by $48.8 \%$ compared to the control and the highest was found to be $72.79 \mu \mathrm{g} / \mathrm{g}$ DW in $2 \mathrm{mg} / \mathrm{L} \mathrm{NAA}+1 \mathrm{mg} / \mathrm{L}$ BAP $+0.1 \mu \mathrm{M}$ GR24 application $(P<0.05)$. In other applications with GR24, this amount was found to be much lower, therefore the increase in the GR24 concentration decreased the amount of phenolic substance compared to the control, regardless of the presence or absence of NAA and BAP (Fig. 3).

Although this is not the case for the amount of chlorogenic acid, the highest amount of chlorogenic acid was found in this application as $46.4 \mu \mathrm{g} / \mathrm{g} \mathrm{DW}$, and also caught our attention as the highest among the analyzed phenolics. GR24 used alone also significantly increased the amount of chlorogenic acid compared to the control (Fig. 3). Rad et al. (2021) obtained $0.680 \mathrm{mg} / \mathrm{g}$ DW chlorogenic acid in caper leaves. There are studies analyzing the effects of auxin and cytokinins on the amount of chlorogenic acid in in vitro cultures of some plants. Erkoyuncu and Yorgancilar (2021) reported that $1 \mathrm{mg} / \mathrm{L} \mathrm{2.4-D} \mathrm{+} 2 \mathrm{mg} / \mathrm{L}$ BAP treated leaf calluses of Echinacea purpurea L. contained $0.23 \mathrm{mg} \mathrm{g}$ chlorogenic acid; Szopo et .al. (2020) also determined the amount of chlorogenic acid as $20 \mathrm{mg} / 100 \mathrm{mg}$ DW in Schisandra rubriflora microshoot extracts. Siahposuh et al. (2011) reported that kinetin stimulates chlorogenic acid production positively in Varthemia persica callus, and replacement of 2,4-D with NAA does not change chlorogenic acid production. 
In our study, caffeic acid was not detected in calluses in any of the application, including the control group (data not shown). According to the findings of Oudah et al. (2019) the amount of caffeic acid in caper leaves was $73.542 \mu \mathrm{g} / \mathrm{ml}$, Rezzan et al. (2013) reported no caffeic acid in the caper leaves collected from Gaziantep/Turkey flora.

Antognoni et al. (2008) reported that the production of a-tocopherol in Amaranthus caudatus and Chenopodium species calli were approximately 40 times lower than the tocopherol content in the plant leaves and other organs. In some cases, this is due to the lack of specialized cell structures (St. Pierre et al. 1999; Pasqua et al. 2003). In our study, the highest amount of a-tocopherol was found in the control group, and it decreased significantly in all applications with GR24. In callus cultures of $C$. spinosa, atocopherol accumulation was approximately 1000 to 5000 times lower than in leaves $(20.19 \pm 31.71$ $\mathrm{mg} / 100 \mathrm{~g}$ ), regardless of the culture medium (Tlili et al. 2009).

In our study, aromatic substance contents of calluses were generally examined under six groups as sulfur compounds, aldehydes, ketones, hydrocarbons and derivatives, alcohols and others (Table 1). In the GR24-only applied group, the total sulfur compound was found to be $87.53 \%$ and the dominant substance was methyl isothiocyanate (556-61-6). The pungent aroma of capers is usually caused by the very sharp methyl isothiocyanate released after an enzymatic reaction with a mustard oil glycoside known as glucocaparin (methyl glucosinolate) (Sozzi et al. 2012). El-Ghorab et al. (2007) and Bakr and El Bishbishy (2016) stated that the predominant essential oil in the caper plant collected from the flora was methyl isothiocyanate at $20.0 \%$ and $24.66 \%$, respectively. In our study, this rate was found to be higher in all applications in caper calluses. Here, we can clearly state that callus culture is a good method for methyl isocyanate production. Zhang (2004) documented the cancer-preventive activity of a significant number of isothiocyanates, mostly of which occur in plants, especially in cruciferous vegetables. Moreover, glucosinolates via their hydrolysis products are among the most powerful antibiotic substances known from higher plants (Louda and Mole, 1991), with an established correlation between the content of glucosinolates (isothiocyanates) and disease resistance (Esteve 2020). Again, $0.2 \mu \mathrm{M}$ GR24 application increased the total aldehyde content from $6.09-7.90 \%$.

2NAA + 1BAP + $0.1 \mu \mathrm{M}$ GR24 increased ketone and hydrocarbon compounds by 10 and 14 folds, respectively, compared to control group. It was realized that the combination of GR24 with the other two plant growth regulators had a positive effect and this effect was directly proportionional to the decrease in GR24 concentration. The dominant compound in ketones was acetoin (513-86-0), and n-hexan (110-543 ) in hydrocarbons and derivatives. The amount of alcohol and other aromatics was reduced in all applications with GR24 compared to the control. This article is the first to present the effect of GR24 on the amount of essential oil in C. spinosa callus. Romeo et al. (2007) recorded $8.42 \%$ sulfur compounds, $12.8 \%$ hydrocarbons and derivatives and 7.48\% alcohol in Eolian capers. Bidabadi and Sharifi (2021) stated that strigolacones (10 $\mu \mathrm{M}$ GR24) increased the essential oil content and yield in Dracocephalum kotschyi under drought stress. They also reported that increasing levels of SL application positively influenced essential oil content and yield in $S$. nemorosa where the lowest salt concentration $(100 \mathrm{mM}$ 
$\mathrm{NaCl}$ ) accompanied with $0.3 \mu \mathrm{M} \mathrm{SL}$, resulted in the highest essential oil content and yield (Sharifi and Bidabadi 2020).

Table 1

Effect of various GR24 concentrations on the aromatic substance of caper calluses

\begin{tabular}{|c|c|c|c|c|}
\hline $\begin{array}{l}\text { Aromatic } \\
\text { compounds }\end{array}$ & $\begin{array}{l}\text { 2NAA + 1BAP } \\
\text { (Control) (\%) }\end{array}$ & $\begin{array}{l}\text { 2NAA+ 1BAP + 0,1 } \\
\mu \mathrm{M} \text { GR24 (\%) }\end{array}$ & $\begin{array}{l}\text { 2NAA+ 1BAP + 0,2 } \\
\mu \mathrm{M} \text { GR24 (\%) }\end{array}$ & $\begin{array}{l}0,2 \mu \mathrm{M} \\
\text { GR24 (\%) }\end{array}$ \\
\hline $\begin{array}{l}\text { Sulphur } \\
\text { compounds }\end{array}$ & 83.58 & 66.97 & 83.27 & 87.53 \\
\hline Aldehydes & 6.09 & 4.88 & 6.45 & 7.90 \\
\hline Ketones & 1.32 & 19.3 & 6.55 & 0.34 \\
\hline $\begin{array}{l}\text { Hydrocarbons and } \\
\text { derivatives }\end{array}$ & 0.56 & 5.8 & 0.83 & 0.62 \\
\hline Alcohols & 6.08 & 1.62 & 1.86 & 3.00 \\
\hline Others & 2.37 & 1.43 & 1.04 & 0.61 \\
\hline
\end{tabular}

In conclusion, in this study, it was observed that GR24 may be effective in the production of phenolic compounds in caper callus cultures. It was realised that both the formation and wet weights of calluses cultured in the medium containing $2 \mathrm{mg} / \mathrm{L} \mathrm{NAA}+1 \mathrm{mg} / \mathrm{L} \mathrm{BAP}+0.1 \mu \mathrm{M}$ GR24 were higher compared to other media, and this was the best application especially in the accumulation of chlorogenic acid, rutin and quercetin phenolics. It was also determined that GR24 used at lower concentrations was more effective, but much studies on this is required in the future. The lack of comprehensive genomic data for most plants with medicinal or nutraceutical properties has made it difficult to use common genomic (eg, microarray-based) approaches to study metabolic pathways. In vitro culture offers an attractive alternative to understanding the regulation of enzymes involved in plant secondary metabolism.

\section{Declarations}

Acknowledgements: This study was supported by Scientific Research Project Management of Süleyman Demirel University (SDUBAP) with project number FYL-2019-7390.

Author contributions: All the authors contributed equally in experiment design, experimentation, analysis and write up of the manuscript

Funding: This study was supported by Scientific Research Project Management of Süleyman Demirel University (SDUBAP) with project number FYL-2019-7390.

Availability of data and material : All data generated or analyzed during this study are included in this article.

\section{Compliance with ethical standards}


Conflict of interest: The authors declare that they have no competing interests.

Consent for publication: The authors declare consent for publication

\section{References}

1. Agusti J, Herold S, Schwarz M, Sanchez P, Ljung K, Dun EA, Brewer PB, Beveridge CA, Sieberer T, Sehr EM, Greb T (2011) Strigolactone signaling is required for auxin-dependent stimulation of secondary growth in plants. Proc Natl Acad Sci USA 108:20242-20247.

https://doi.org/10.1073/pnas.1111902108

2. Al-Ashoush A (2017) Effect of some chemical factors on production of pentacyclic triterpenoids in callus and cell suspension culture of Lantana camara $L$. The University of Jordan, Dissertion

3. Antognoni M, Faudale F, Poli S, Biondi F (2008) Methyl jasmonate differentially affects tocopherol content and tyrosine amino transferase activity in cultured cells of Amaranthus caudatus and Chenopodium quinoa. Plant Biol 11:161-169. https://doi.org/10.1111/j.1438-8677.2008.00110.x

4. Arena A, Bisignano G, Pavone B, Tomaino A, Bonina FP, Saija A, Cirstani M, D'Arrigo M, Trombetta D (2008) Antiviral and immunomodulatory effect of a lyophilized extract of Capparis spinosa L. buds. Phytoter Res 22:313-317. https://doi.org/10.1002/ptr.2313

5. Argentieri M, Macchia F, Papadia P, Fanizzi FP, Avato P (2012) Bioactive compounds from Capparis spinosa subsp. Rupestris Ind Crop Prod 36:65-69. https://doi.org/10.1016/j.indcrop.2011.08.007

6. Bahrani MJ, Ramazani Gask M, Shekafandeh A, Taghvaei M (2008) Seed germination of wild caper (Capparis spinosa L., var. parviflora) as affected by dormancy breaking treatments and salinity levels. Seed Sci Technol 36:776-780. https://doi.org/10.1016/j.bjp.2016.04.001

7. Bakr RO, El Bishbishy MH (2016) Profile of bioactive compounds of Capparis spinosa var. aegyptiaca growing in Egypt. Rev Bras Farmacogn 26:514-520. https://doi.org/10.1016/j.bjp.2016.04.001

8. Behnaz M, Davood EA, Atena A (2013) Diurnal change in rutin content in Capparis spinosa growing wild in Tafresh/Iran. Eur J Exp Biol 3:30-34

9. Bidabadi SS, Sharifi P (2021) Strigolactone and methyl jasmonateinduced antioxidant defense and the composition alterations of diferent active compounds in Dracocephalum kotschyi Boiss under drought stress. J Plant Growth Regul 40:878-889. https://doi.org/10.1007/s00344-020-10157-6

10. Brewer PB, Dun EA, Ferguson BJ, Rameau C, Beveridge CA (2009) Strigolactone acts downstream of auxin to regulate bud outgrowth in pea and Arabidopsis. Plant Physiol 150:482-493. https://doi.org/10.1104/pp.108.134783

11. Davis PH (1982) Flora of Turkey and the east Aegean Islands. Edinburgh University Press, Edinburgh

12. El-Ghorab A, Shibamoto T, Özcan MM (2007) Chemical composition and antioxidant activities of buds and leaves of capers (Capparis ovata Desf. var.canescens) cultivated in Turkey. J Essent Oil Res 19:72-77. https://doi.org/10.1080/10412905.2007.9699233 
13. Erkoyuncu MT, Yorgancilar M (2021) Optimization of callus cultures at Echinacea purpurea L. for the amount of caffeic acid derivatives. Electron J Biotechnol 51:17-27.

https://doi.org/10.1016/j.ejbt.2021.02.003

14. Esteve M (2020) Mechanisms underlying biological effects of cruciferous glucosinolate-derived isothiocyanates/indoles: A focus on metabolic syndrome. Front Nutr 7:111. https://doi.org/10.3389/fnut.2020.00111 ()

15. Germanà MA, Chiancone $B$ (2009) In vitro germination and seedling development of caper (Capparis spinosa L.) mature seeds. Acta Hortic 839:181-186.

https://doi.org/10.17660/ActaHortic.2009.839.21

16. Germano MP, Pasquale RDE, Angelo VD, Catania S, Silvari V, Costa C (2002) Evaluation of extracts and isolated fraction from Capparis spinosa L. buds as an antioxidant source. J Agric Food Chem 27:1168-1171. https://doi.org/10.1021/jf010678d

17. Grobbelaar MC, Makunga NP, Stander MA, Kossmann J, Hills PN (2014) Effect of strigolactones and auxins on growth and metabolite content of Sutherlandia frutescens (L.) R. Br. microplants in vitro. PCTOC 117:401-409. https://doi.org/10.1007/s11240-014-0449-9

18. Goda SM, Ahmed SA, El Sherif F, Hassanean HA, Ibrahim AK (2017) Genetically stable plants with boosted flavonoids content after in vitro regeneration of the endangered Capparis spinosa L. Glob Drug Therap 2:1-7. https://doi.org/10.15761/GDT.1000124

19. Haifa AY, Emna M, Wafa R, Lamia H, Slim R, Mohamed NR, Zeineb GG (2016) Phenolic composition and antioxidant activity of aqueous and ethanolic leaf extracts of six Tunisian species of genus Capparis-Capparaceae. Ind Crop Prod 92:218-226. https://doi.org/10.1016/j.indcrop.2016.07.051

20. Hayward A, Stirnberg P, Beveridge C, Leyser $O$ (2009) Interactions between auxin and strigolactone in shoot branching control. Plant Physiol 15:400-412. https://doi.org/10.1104/pp.109.137646

21. Koltai $H$ (2015) Cellular events of strigolactone signalling and their crosstalk with auxin in roots. J Exp Bot 66:4855-4861. https://doi.org/10.1093/jxb/erv178

22. Kumari M, Asthana N, Kumari R (2015) Plantlets regeneration through callus culture in Capparis spinosa Linn. IJEK 2:34-40

23. Louda S, Mole S (1991) Glucosinolates: chemistry and ecology. In: Rosenthal GA, Berenbaum MR (eds) Herbivores: Their interactions with secondary plant metabolites. San Diego, California, pp 123164

24. Matthaus B, Ozcan M (2005) Glucosinolates and fatty acid, sterol and tocopherol composition of seed oils from Capparis spinosa var. spinosa and Capparis ovata desf. var. canescens (Coss.) Heywood. J Agric Food Chem 53:7136-7141. https://doi.org/10.1021/jf051019u

25. Mdodana NT (2012) The effects of the synthetic strigolactone GR24 on Arabidopsis thaliana callus culture. Dissertion, University of Stellenbosch

26. Murashige T, Skoog F (1962) A revised medium for rapid growth and bio assays with tobacco tissue cultures. Physiol Plant 15:473-497 
27. Musallam I, Mahmud D, Rida AS (2011) Micropropagation of cappers (capparis spinosa) from wild plants. Funct Plant Sci Biotechnol 5:17-21

28. Musallam I, Duwayri M, Shibli R, Alali F (2012) Investigation of rutin content in different plant parts of wild caper (Capparis spinosa L.) populations from Jordan. Res J Med Plant 6:27-36. https://doi.org/10.3923/rjmp.2012.27.36

29. Palacio L, Cantero JJ, Cusidó RM, Goleniowski ME (2012) Phenolic compound production in relation to differentiation in cell and tissue cultures of Larrea divaricata (Cav.). Plant Sci 193:1-7. https://doi.org/10.1016/j.plantsci.2012.05.007

30. Panico AM, Cardile V, Garufi F, Puglia C, Bonina F, Ronsisvalle G (2005) Protective effect of Capparis spinosa on chondrocytes. Life Sci 77:2479-2488. https://doi.org/10.1016/j.lfs.2004.12.051

31. Pasqua G, Monacelli B, Silvestrini A (2003) Accumulation of essential oils in relation to root differentiation in Angelica archangelica L. Eur J Histochem 47:87-90. https://doi.org/10.4081/811

32. Rad MK, Ghani A, Ghani E (2021) In vitro effects of Capparis spinosa L. extract on human sperm function, DNA fragmentation, and oxidative stres. J Ethnopharmacol 269:113702. https://doi.org/10.1016/j.jep.2020.113702

33. Rajesh P, Selvamani P, Latha S, Saraswathy A, Kannan V (2009) A review on chemical and medicobiological applications of capparidaceae family. Pharmacogn Rev 3:378-387

34. Rezzan A, Ozan EE, Huseyin S, Oktay Y, Nimet B (2013) Phenolic components, antioxidant activity, and mineral analysis of Capparis spinosa L. Afr. J Biotechnol 12:6643-6649

35. Romeo V, Ziino M, Giuffrida D, Condurso C, Verzera A (2007) Flavour profile of capers (Capparis spinosa L.) from the eolian archipelago by hs-spme/gc-ms. Food Chem 101:1272-1278. https://doi.org/10.1016/j.foodchem.2005.12.029

36. Shah RR, Subbaiah KR, Mehta AR (1976) Hormonal effect on polyphenol accumulation in Cassia tissues cultured in vitro. Canad J Bot 54:1240-1245. https://doi.org/10.1139/b76-134

37. Oudah SK, Al-Salih RMH, Gusar SH, Roomi AB (2019) Study of the role of polyphenolic extract of Capparis spinosa L. leaves as acute toxicity and antibacterial agent. Plant Arch 19:3821-3829

38. Sharifi P, Bidabadi SS (2020) Strigolactone could enhances gas-exchange through augmented antioxidant defense system in Salvia nemorosa L. plants subjected to saline conditions stres. Ind Crop Prod 151:112460. https://doi.org/10.1016/j.indcrop.2020.112460

39. Sher H, Alyemeni MN (2010) Ethnobotanical and pharmaceutical evaluation of Capparis spinosa L, validity of local folk and Unani system of medicine. J Med Plants Res 4:1751-1756

40. Siahpoush A, Ghasemi N, Shams Ardakani M, Asghari G (2011) Production of chlorogenic acid in Varthemia persica DC (var. persica) callus cultures. Res Pharm Sci 6:63-69

41. Sozzi GO, Chiesa A (1995) Improvement of caper (Capparis spinosa L.) seed germination by breaking seed coat-induced dormancy. Sci Hortic 62:255-261. https://doi.org/10.1016/0304-4238(95)00779$S$ 
42. Sozzi GO, Vicente A (2006) Capers and Caperberries, Handbook of Herbs and Spices. CRC Press, Boca Raton, pp 230-256

43. St-Pierre B, Vazquez-Flota FA, De Luca V (1999) Multicellular compartmentation of Catharanthus roseus alkaloid biosynthesis predicts intercellular translocation of a pathway intermediate. Plant Cell 11:887-900. https://doi.org/10.1105/tpc.11.5.887

44. Szopa A, Dziurka M, Granica S, Klimek-Szczykutowicz M, Kubica P, Warzecha A, Jafernik K, Ekiert H (2020) Schisandra rubriflora plant material and in vitro microshoot cultures as rich sources of natural phenolic antioxidants. Antioxidants (Basel) 9(6):488. https://doi.org/10.3390/antiox9060488

45. Tlili N, Nasri N, Saadaoui E, Khaldi A, Triki S (2009) Carotenoid and tocopherol composition of leaves, buds and flowers of Capparis spinosa grown wild in Tunisia. J Agric Food Chem 57:5381-5385. https://doi.org/10.1021/jf900457p

46. Tlili N, Khaldi A, Triki S, Munné-Bosch S (2010) Phenolic compounds and vitamin antioxidants of caper (Capparis spinosa). Plant Foods Hum Nutr 65:260-265. https://doi.org/10.1007/s11130-0100180-6

47. Tlili N, Ferianib A, Saadouid E, Nasria N, Khaldid A (2017) Capparis spinosa leaves extract: source of bioantioxidants with nephroprotective and hepatoprotective effects. Biomed Pharmacother 87:171179. https://doi.org/10.1016/j.biopha.2016.12.052

48. Trombetta D, Occhiuto F, Perri D, Puglia C, Santagati NA, Pasquale AD, Saija A, Bonina F (2005) Antiallergic and antihistaminic effect of two extracts of Capparis spinosa L. flowering buds. Phytother Res 19:29-33. https://doi.org/10.1002/ptr.1591

49. Tyagi P, Khanduja S, Kothar SL (2010) In vitro culture of Capparis decidua and assessment of clonal fidelity of the regenerated plants. Biol Plant 54:126-113. https://doi.org/10.1007/s10535-010-0019$X$

50. Udomsuk L, Jarukamjorn K, Tanaka H, Putalun W (2011) Improved isoflavonoid production in Pueraria candollei hairy root cultures using elicitation. Biotechnol Lett 33:369-374. https://doi.org/10.1007/s10529-010-0417-3

51. Wang YT, Gan L, Liu W, Yu LJ, Li MT (2007) Research on the callus inducing and the cell growth and metabolism characteristics of Capparis spinosa L. Progr Mod Biomed 7:1779-1783

52. Wu Y, Dor E, Hershenhorn J (2017) Strigolactones affect tomato hormone profile and somatic embryogenesis. Planta 245:583-594. https://doi.org/10.1007/s00425-016-2625-0

53. Zhang Y (2004) Cancer-preventive isothiocyanates: measurement of human exposure and mechanism of action. Mutat Res 555:173-190. https://doi.org/10.1016/j.mrfmmm.2004.04.017

54. Zhou HF, Xie C, Jian R, Kang J, Li Y, Zhuang CL, Yang F, Zhang L, Lai L, Wu T, Wu X (2011) Bioflavonoids from Caper (Capparis spinosa L.) fruits and their effects in inhibiting NF-kappa B activation. J Agric Food Chem 59:3060-3065. https://doi.org/10.1021/jf105017j

55. Zulfqar H, Shahbaz M, Ahsan M, Nafees M, Nadeem H, Akram M, Maqsood A, Ahmar S, Kamran M, Alamri S, Siddiqui MH, Saud S, Fahad S (2020) Strigolactone (GR24) induced salinity tolerance in 
sunflower (Helianthus annuus L.) by ameliorating morpho-physiological and biochemical attributes under in vitro conditions. J Plant Growth Regul. https://doi.org/10.1007/s00344-020-10256-4

\section{Figures}

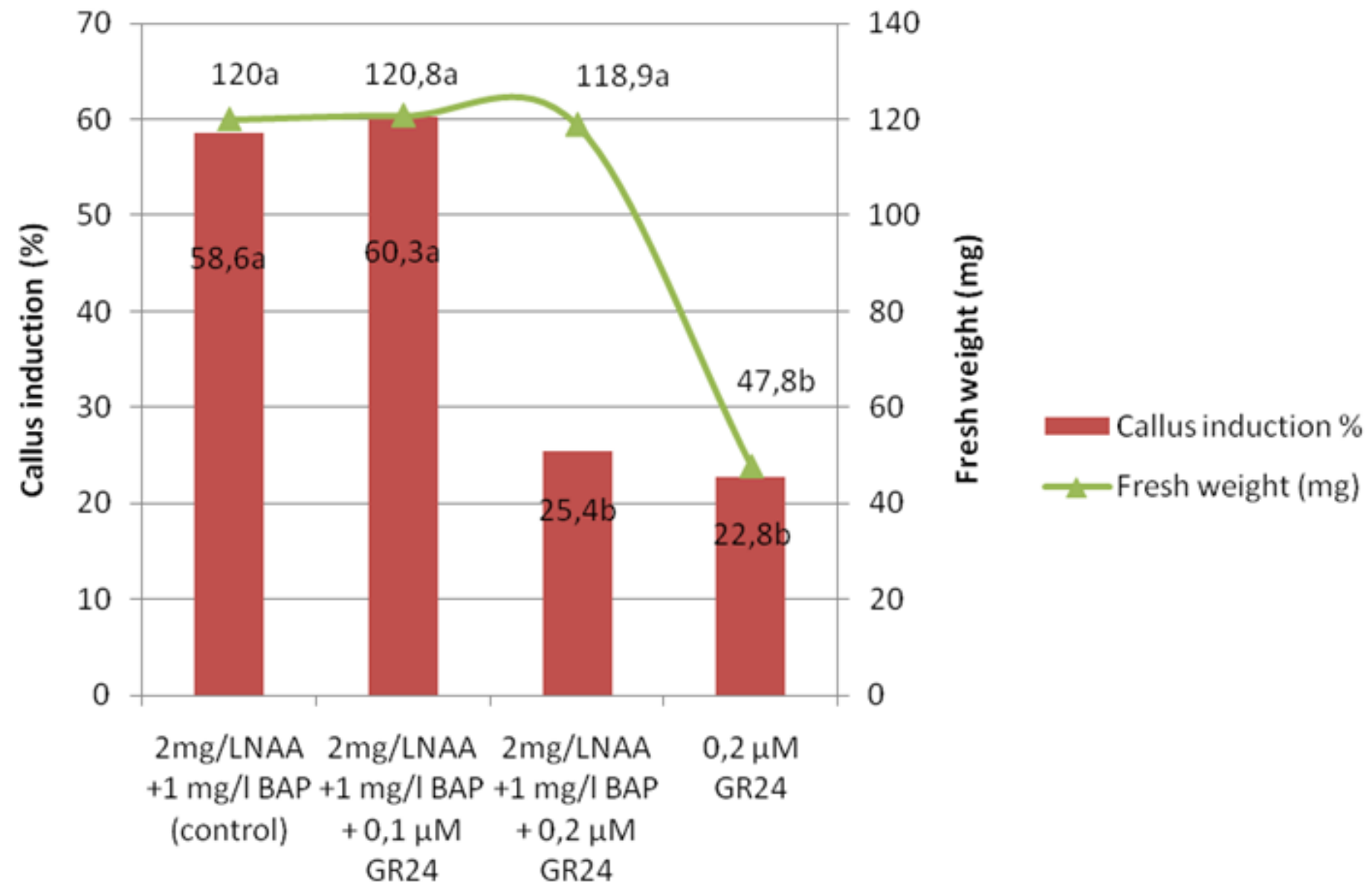

\section{Figure 1}

Effect of various GR24 concentrations on caper callus formation and fresh weight * Differences between means shown by individual letters are significant $(P<0.05)$ 


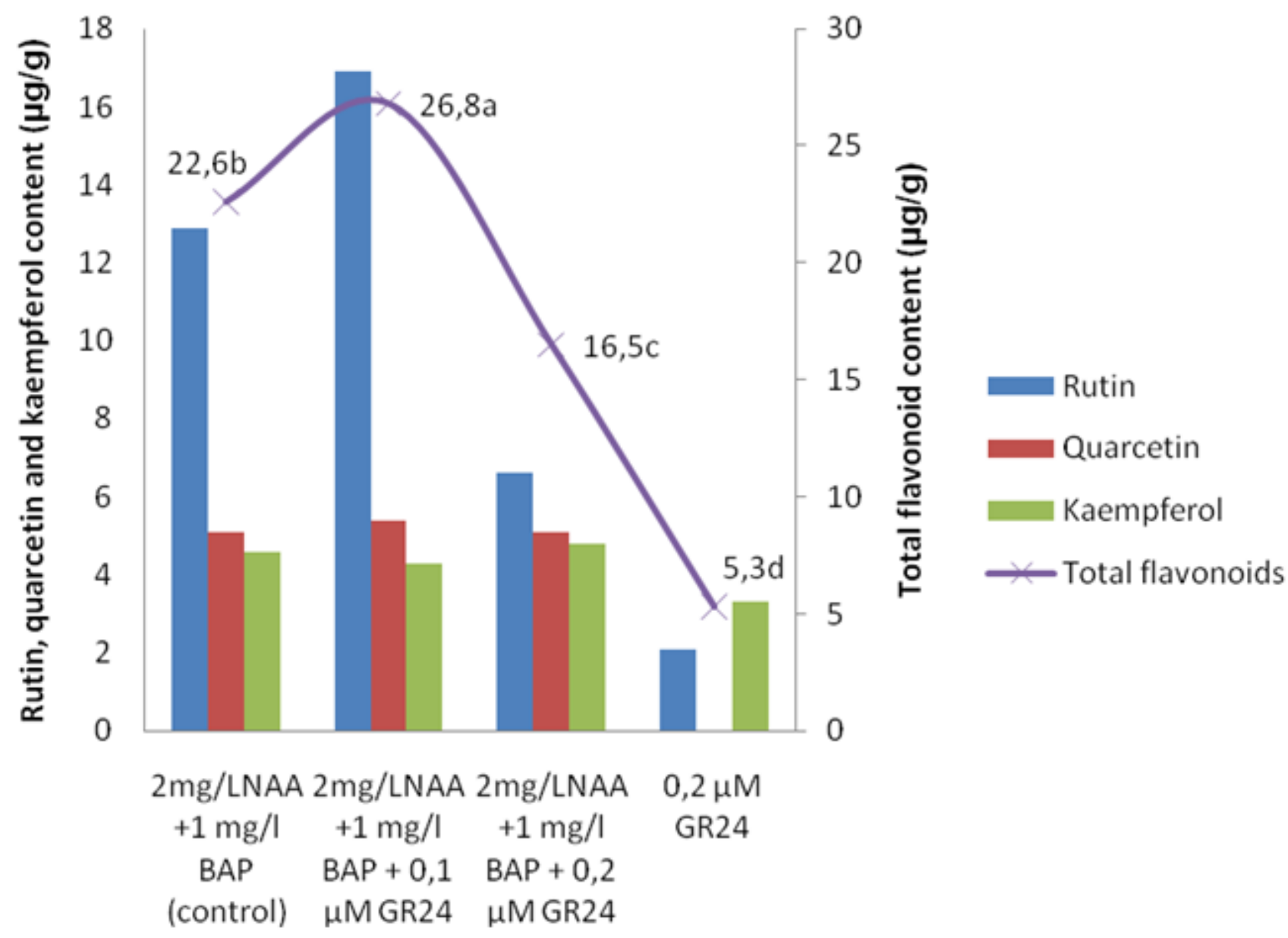

Figure 2

The effect of various GR24 concentrations on the total flavonoid, rutin, quercetin and kaempferol in caper callus. * The differences between the means shown by individual letters are significant $(P<0.05)$ 


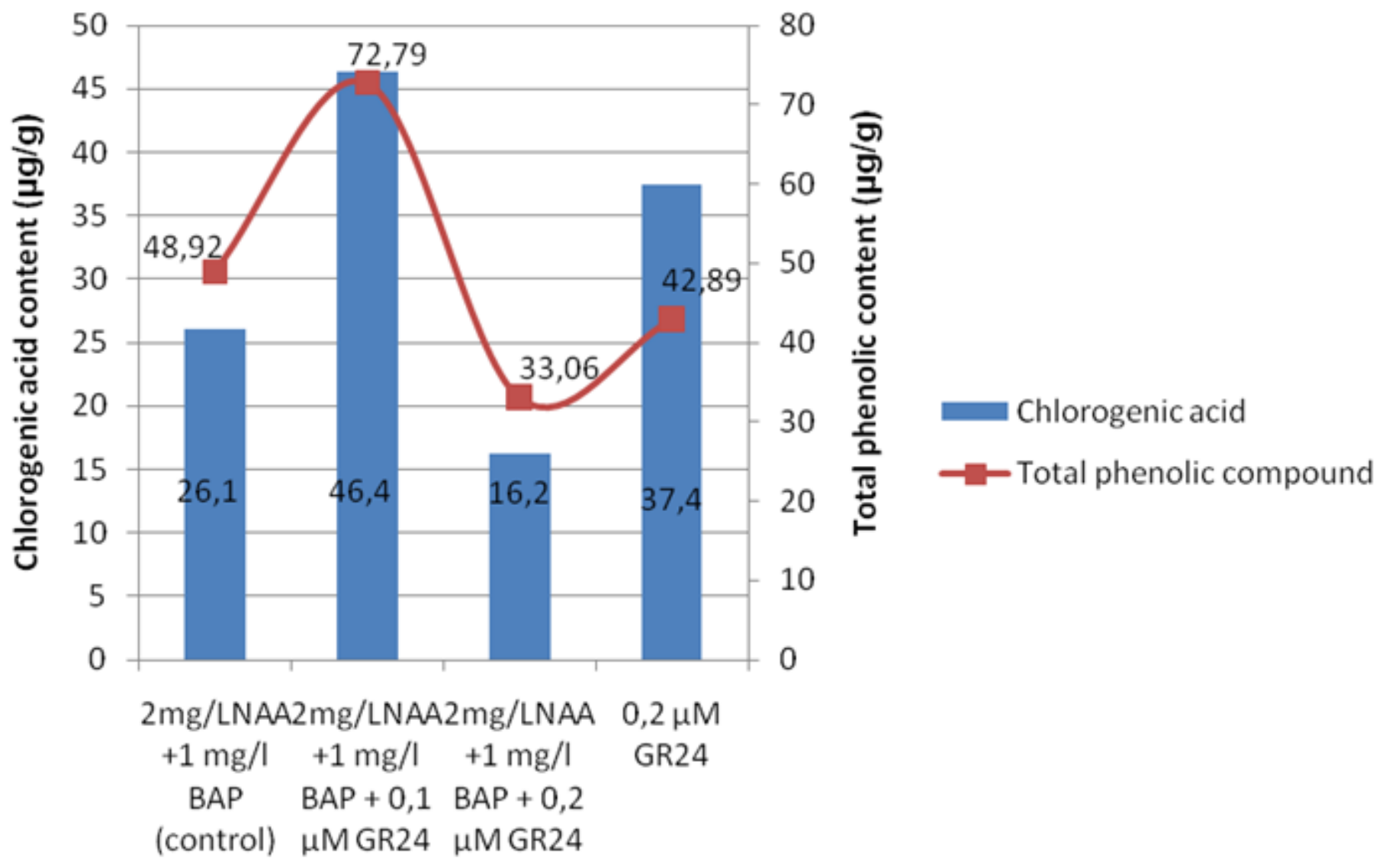

Figure 3

Effect of various GR24 concentrations on the total phenolic substance and chlorogenic acid in caper calluses. * The differences between the means shown by individual letters are significant $(P<0.05)$ 